\title{
Critical Role of TrkB and Brain-Derived Neurotrophic Factor in the Differentiation and Survival of Retinal Pigment Epithelium
}

\author{
Zheng Z. Liu, Ling Q. Zhu, and Fernette F. Eide \\ Department of Neurology, University of Chicago, Chicago, Illinois 60637
}

In the vertebrate eye, the retinal pigment epithelium (RPE) and the neural retina arise from a single layer of neuroectoderm. Factors influencing the differentiation of retinal neurons have been identified; however, little is known about molecules directing the differentiation of the RPE. Here we have found that the neurotrophin brain-derived neurotrophic factor (BDNF) plays an autocrine role in the differentiation and survival of Xenopus laevis RPE. Fluorescent in situ hybridization studies showed a precise co-expression of BDNF and its receptor trkB in the retinal neuroepithelium and actively differentiating RPE; in vitro studies demonstrated survivaland differentiation-promoting effects in serum-free explants and dissociated cultures. When a dominant negative mutant of the trkB receptor was expressed in developing embryos, severe arrest of RPE differentiation was seen with persistence of nestin- and Notch-positive neuroblasts.

Key words: BDNF; trkB; neurotrophin; retinal pigment epithelium; differentiation; retina; dominant negative
The vertebrate retina differentiates from a double layer of neuroepithelial precursors constituting the optic cup (for review, see Park and Hollenberg, 1993). Cells of the outer layer withdraw from the cell cycle to differentiate as a single layer of pigmented cuboidal epithelium, whereas cells of the inner layer continue proliferating and differentiating until the entire multilayered neural retina is generated. Numerous molecules, including basic fibroblast growth factor, brain-derived neurotrophic factor (BDNF), neurotrophin-3, insulin-like growth factor I, laminin, retinoic acid, and mammalian hairy and Enhancer of Split Homolog 1 (Pittack et al., 1991; Cohen-Cory and Fraser, 1994; Kelley et al., 1994; Pittack and Reh, 1994; Bovolenta et al., 1996; Frade et al., 1996; Tomita et al., 1996), have been implicated in the differentiation of the neural retina; however, little is known about putative differentiation factors for the RPE.

The neurotrophins are a family of growth factors that have potent survival- and differentiation-promoting effects in neuronal and epithelial cell populations (Wheeler and Bothwell, 1992; Eide et al., 1993; Hallbook et al., 1993; Brill et al., 1995; Mitsiadis and Luukko, 1995). Receptors for the neurotrophins (the trks) are found throughout the visual system, including in germinal retinal neuroepithelium and most retinal cell groups (LaVail et al., 1992; Cohen-Cory and Fraser, 1994; Okazawa et al., 1994; Unoki and LaVail, 1994; Koide et al., 1995; Perez and Caminos, 1995; Ugolini et al., 1995; Cohen-Cory et al., 1996). BDNF became a particularly interesting candidate for trophic activity in the RPE because of its light inducibility (Okazawa et al., 1994) and its ability to protect photoreceptors from damage by light in vivo (LaVail et al., 1992). Among its many critical functions in vision,

Received June 10, 1997; revised Aug. 18, 1997; accepted Aug. 28, 1997.

This work was supported by National Institutes of Health Grant K1100568 (F.F.E.) and Howard Hughes Medical Institute Resource Allocation Award from the University of Chicago Biological Sciences Division (F.F.E.). We thank W. Harris and R. Dorsky (University of California San Diego) for cDNA, R. McKay (National Institutes of Health) and D. Sakaguchi (Iowa State University) for antibodies, and M. al-Ulbaidi, L. F. Reichardt, and E. Schwartz for helpful comments on this work.

Correspondence should be addressed to Dr. Fernette Eide, Department of Neurology, MC 2030, University of Chicago, 5841 South Maryland Avenue, Chicago, IL 60637.

Copyright (C) 1997 Society for Neuroscience $0270-6474 / 97 / 178749-07 \$ 05.00 / 0$ the RPE protects photoreceptors from injury by strong light and regulates ion conductances for light-dark adaptation (for review, see Bok, 1993).

\section{MATERIALS AND METHODS}

cDNAs and probes. The cDNA clone for Xenopus Notch (AN119) was generously provided by R. I. Dorsky and W. A. Harris (University of California San Diego) (Dorsky et al., 1995). cDNAs for Xenopus BDNF and trkB (Cohen-Cory et al., 1994) were obtained by reverse transcription-PCR from oligo(dT)-primed reverse transcription of poly $\left(\mathrm{A}^{+}\right)$RNA isolated from stage 30 embryo heads. The trkB primers (5', GACATTAAAAGATGCCAGTGACAATG; 3', CGCGTTGCCAGCAGCCGC) amplified a 661 bp region, which included the kinasecontaining domain of trkB. The specificity of this probe for trkB has been described previously by Cohen-Cory and Fraser (1994). The primers for BDNF (5', CTCTGACCCAGCCAGGCGT; 3', AGTGTACATACACAAGAAGTGTC) were based on the entire coding sequence for the mature protein (Isackson et al., 1991; $339 \mathrm{bp}$ ). The PCR products were ligated into PCR II (InVitrogen TA cloning kit), and then the sequences were confirmed by restriction analysis and double-stranded sequencing using Sequenase (United States Biochemicals, Cleveland, $\mathrm{OH}$ ). In vitro transcription was used to generate antisense cRNA probes incorporating fluorescein-12-uridine-5-triphosphate (fluorescein-12-UTP; Boeringer Mannheim, Indianapolis, IN) or chromaridetetramethyrhodamine UTP (TMR-5-UTP; Molecular Probes, Eugene, OR). The plasmids containing the interested regions of genes for trkB, BDNF, and Notch were linearized and purified for use in the labeling reaction. After reactions, the labeled probes were precipitated with $\mathrm{DEPC}-\mathrm{NaAO}_{3}$ and reconstituted in RNase-free water.

Tagged wild-type and mutant TrkB constructs. Construction of tagged wild-type and mutant trkB receptors has been described previously (Eide et al., 1996). Briefly, site-directed mutagenesis was used to introduce a Lys ${ }^{560} \rightarrow$ Met $^{560}$ substitution at a critical lysine in the ATP binding site of the full-length trkB receptor. Replacement by a methionine at this site resulted in a kinase-deficient receptor, which could interrupt signaling by forming nonfunctional heterodimers with wild-type receptors (Eide et al., 1996). To distinguish wild-type and mutant trkB receptors, small epitope tags were attached by PCR to the $\mathrm{C}$ termini of each receptor. We had previously found that the attachment of tags at this location had no interference with receptor activation or downstream signal transduction (Eide et al., 1996). The wild-type trkB receptor was tagged using an epitope from influenza virus hemagglutinin (Niman et al., 1983); the mutant receptor was tagged with an epitope from the c-myc protooncogene (myc) (Evan et al., 1985). Mutations were confirmed by DNA sequencing using the dideoxy chain termination technique (United States 
Biochemical). Both receptors were cloned under the control of the frog $\beta$-globin promoter in vector pSP64T (Krieg and Melton, 1984).

In situ hybridization. Xenopus embryos were harvested at various stages (stages 26-45) and then fixed in BOSCO (95:5:0.25\% ethanol/acetic acid/chromium trioxide) as described previously (O'Keefe et al., 1991). After successive dehydration in alcohol and immersion in xylene, embryos were embedded in Paraplast according to the manufacturer's instructions (Oxford Labware). Six-micrometer sections were collected on the poly-L-lysine-coated RNase-free slides, deparaffinized, rehydrated, and then deproteinated by proteinase $\mathrm{K}(125 \mathrm{mg} / \mathrm{ml})$. Sections were then treated with triethanolamine-acetic anhydride, dehydrated, and prehybridized in the presence of $0.3 \mathrm{M} \mathrm{NaCl}, 0.1 \mathrm{M} \mathrm{NaPO}_{4}, \mathrm{pH} \mathrm{6.8,}$ $5 \mathrm{~mm}$ EDTA, $0.02 \%$ (w/v) Ficoll $400,0.02 \%$ polyvinylpyrrolidone, $0.02 \%$ bovine serum albumin (fraction V), $40 \%$ formamide, $10 \%$ dextran sulfate, total yeast tRNA $(0.1 \mathrm{mg} / \mathrm{ml})$, and $0.01 \mathrm{M} \mathrm{DTT}$ at $50^{\circ} \mathrm{C}$ as described previously (Angerer et al., 1987). Sections were hybridized with fluorescein or rhodamine sense or antisense riboprobes of Xenopus Notch, trk B, and BDNF. After hybridizations, sections were washed in successive washes of $2 \times, 1 \times$, and $0.5 \times$ SSC. Sections were mounted in 4:1 glycer$\mathrm{ol} / 2 \times \mathrm{SSC}$ containing sodium azide $(25 \mathrm{mg} / \mathrm{ml})$.

Optic cup cultures. For optic cup explants, stage 26 Xenopus embryos were killed in $0.1 \%$ tricaine, and then optic vesicles were dissected aseptically in a modified HBSS described by Defoe and Easterling (1994). Explants were plated onto thin coats of growth factor-reduced Matrigel (Becton Dickinson, Mountain View, CA) in NCTC-135 media (Sigma, St. Louis, MO) containing $10 \mathrm{mg} / \mathrm{ml}$ insulin, $5.5 \mathrm{mg} / \mathrm{ml}$ transferrin, 6.7 $\mathrm{ng} / \mathrm{ml}$ sodium selenite, $0.11 \mathrm{mg} / \mathrm{ml}$ sodium pyruvate, $1 \mathrm{mg} / \mathrm{ml}$ bovine serum albumin, $10 \mathrm{mg} / \mathrm{ml}$ linoleic acid-albumin, $20 \mathrm{nM}$ hydrocortisone, $10 \mathrm{nM}$ triiodothyronine, $0.3 \mathrm{mg} / \mathrm{ml}$ putrescine, $50 \mathrm{ng} / \mathrm{ml}$ epidermal growth factor (Sigma), and $50 \mathrm{mg} / \mathrm{ml}$ aprotinin. A BDNF-neutralizing antibody was purchased from R \& D Systems (Minneapolis, MN) and used according to the manufacturer's instructions. The $50 \%$ neutralization dose $\left(\mathrm{ND}_{50}\right)$ for this antibody on dorsal root ganglion cultures had previously been estimated at $5-15 \mu \mathrm{g} / \mathrm{ml}$ (R \& D Systems). The $\mathrm{ND}_{100}$ was $50 \mu \mathrm{g} / \mathrm{ml}$. Twenty-four explants were studied (eight controls, eight 15 $\mu \mathrm{g} / \mathrm{ml} \mathrm{BDNF}$ antibody, and eight $50 \mu \mathrm{g} / \mathrm{ml}$ BDNF antibody). All cultures were incubated at $23^{\circ} \mathrm{C}$ in a $5 \% \mathrm{CO}_{2}$ incubator.

For survival studies, fifty stage 45 optic cups were dissociated in $0.05 \%$ trypsin and $2.4 \%$ dispase and then distributed equally into to $1610 \mathrm{~mm}$ wells (eight controls and eight BDNF-treated) coated with growth factorreduced Matrigel as described above. Cells were allowed to attach overnight in the defined media described above plus $10 \%$ fetal bovine serum (FBS). After attachment was allowed to occur, cells were washed and maintained in serum-free media. Media were changed every $48 \mathrm{hr}$ to remove cell debris. Only pigmented cells were counted. Attachment rates were compared using the binomial proportions test (Rosner, 1995). The life table method was used to estimate survival functions for the two groups each day (Collett, 1994). The log-rank test (Collett, 1994) was used to determine statistical differences in survival between control and BDNF-treated cultures.

In vitro transcription, generation, and injection of embryos. cRNA was prepared as described previously (Eide et al., 1996) using a kit from Promega (Madison, WI) and RNeasy columns from Qiagen (Chatsworth, CA). Embryos were generated in human chorionic gonadotropin-primed female Xenopus as previously described by MacNicol et al. (1993). Briefly, milked oocytes were fertilized in vitro in a $0.2 \times$ modified Barth's saline solution containing HEPES (MBSH). Zygotes were briefly treated wth $2 \%$ cysteine to remove the gelatinous extracellular matrix and then transferred to $1 \times \mathrm{MBSH}$ containing $5 \%$ Ficoll. Embryos were injected with RNase-free water or cRNA into one cell of a two-cell embryo.

Whole-mount immunohistochemistry, immunofluorescence, and Western blotting. For whole-mount immunohistochemistry, stage 32 embryos were fixed in Dent fixative overnight (Klymkowsky and Hanken, 1991) and then bleached in $10 \%$ hydrogen peroxide/Dent fixative for $3 \mathrm{~d}$. After

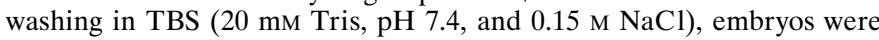
incubated in anti-c-myc antibody (9E10; Santa Cruz Biotechnology, Santa Cruz, CA) in 95\% normal goat serum and 5\% DMSO in the presence of 0.1 thimoserol. After extensive washing in TBS, embryos were incubated with horseradish peroxidase (HRP)-conjugated goat anti-mouse IgG (Amersham Life Sciences). Embryos were again extensively washed in TBS and then reacted with Sigma Fast DAB for 15-30 min. The reactions were stopped by dehydration in methanol and then cleared in benzyl alcohol and benzyl benzoate as described elsewhere (Klymkowsky and Hanken, 1991).

For immunofluorescence of sectioned tissue, embryos were fixed in
Dent fixative, embedded in Paraplast, and then collected in $6 \mu \mathrm{m} \mathrm{sec-}$ tions. After incubation in the anti-c-myc antibody $(9 \mathrm{E} 10 ; 1 \mu \mathrm{g} / \mathrm{ml})$, anti-nestin (a gift from R. D. G. McKay, National Institutes of Health) (Tohyama et al., 1992), XAP-1 (a gift from D. Sakaguchi (Iowa State University) (Harris and Messersmith, 1992), or anti-cellular retinaldehyde binding protein (CRALBP; a gift from J. Saari, University of Washington). Sections were incubated in FITC-conjugated anti-mouse or rabbit IgG, washed in PBS, and then mounted in 4:1 glycerol/PBS containing sodium azide $(25 \mathrm{mg} / \mathrm{ml})$. In immunofluorescent studies involving CRALBP, tissues were briefly treated with a bleaching solution consisting of $0.25 \%$ potassium permanganate and $5 \%$ oxalic acid.

For Western immunoblotting analysis, stage 26 embryos were lysed in $50 \mathrm{~mm}$ NaCL, $50 \mathrm{~mm} \mathrm{NaF}, 30 \mathrm{~mm}$ sodium pyrophosphate, $5 \mathrm{~mm}$ EDTA, $10 \mathrm{~mm}$ Tris, pH 7.4, $1 \%$ Triton X-100 containing 2 mM PMSF, $25 \mu \mathrm{M}$ leupeptin, $10 \mu \mathrm{M}$ pepstatin $\mathrm{A}, 0.2 \mathrm{U} / \mathrm{ml}$ aprotinin, and $1 \mathrm{~mm}$ vanadate. After clearing by centrifugation, lysates were precleared with normal goat serum, immunoprecipitated with an anti-c-myc antibody (9E10; 1 $\mathrm{mg} / \mathrm{ml}$ ), collected with protein G plus agarose (Santa Cruz Biotechnology), boiled in Laemmli's buffer (Laemmli, 1970), and then separated on 7.5\% SDS-PAGE. Proteins were transferred onto nitrocellulose membranes (Amersham, Arlington Heights, IL), washed in TBS, and then blocked in 3\% BSA and 5\% dry milk in TBS with Tween 20 (TBST). After washing, membranes were incubated in 9E10 antibody $(1 \mu \mathrm{g} / \mathrm{ml})$ diluted in blocking buffer for $45 \mathrm{~min}$, washed in TBST, and then incubated in HRP-conjugated goat anti-mouse IgG diluted 1:3000 in blocking buffer. After washing in TBST, blots were developed using an enhanced chemiluminesce kit from Amersham.

Cresyl violet-eosin Y staining. For cresyl violet-eosin Y staining, embryos were fixed in Dent fixative and cleared in benzyl alcohol and benzyl benzoate as described above, embedded in Paraplast, and then collected in $6 \mu \mathrm{m}$ sections. Sections were then stained in $0.1 \%$ cresyl violet and eosin Y and then mounted in Permount (Fisher Scientific, Houston, TX).

\section{RESULTS}

\section{Notch, BDNF, and TrkB mRNA in the early optic cup}

To determine whether trkB transcripts were present in the early Xenopus optic cup, double fluorescent in situ hybridization (FISH) studies were performed using probes for the neuroepithelial marker Notch (Artavanis-Tsakonas et al., 1991) and the kinase-containing region of trkB (Cohen-Cory and Fraser, 1994). Figure $1, A-C$, shows a single section (viewed en face) through a Nieuwkoop and Faber (1956) stage 26 optic cup probed with Notch (Fig. $1 A$ ), trkB (Fig. 1B), and Notch and trkB combined (Fig. $1 C$ ). A precise overlap is seen between Notch- and trkBexpressing cells, suggesting that, at least at this stage, full-length trkB transcripts are expressed homogenously throughout the optic cup. Sense probes for Notch and trkB showed a complete absence of signal (data not shown). Figure 1, $D-F$, shows a stage 28 optic cup probed with trkB (Fig. $1 D$ ), BDNF (Fig. 1E), and trkB and BDNF (Fig. $1 F$ ). At this stage cells appear to have begun segregating into different differentiating cell populations. BDNF- and trkB-expressing cells can be seen in the outermost layer, the region of the presumptive RPE.

\section{Patterns of TrkB, BDNF, and Notch transcripts in the RPE precursor layer and actively differentiating RPE}

By stage 30, RPE progenitors appeared to have aligned into a more distinct (and single) layer of cells co-expressing trkB and BDNF (Fig. 1I). Examination of Notch transcripts at this stage showed persistent high levels in the outermost layers of the retina (Fig. 1J). By the time the first pigment granules were detected in the RPE (stage 32), however, trkB and Notch transcripts diverged; kinase-containing trkB transcripts remained at high levels in the actively differentiating RPE layer (Fig. $1 K, L)$, whereas Notch had become downregulated (Fig. 1M,N). 

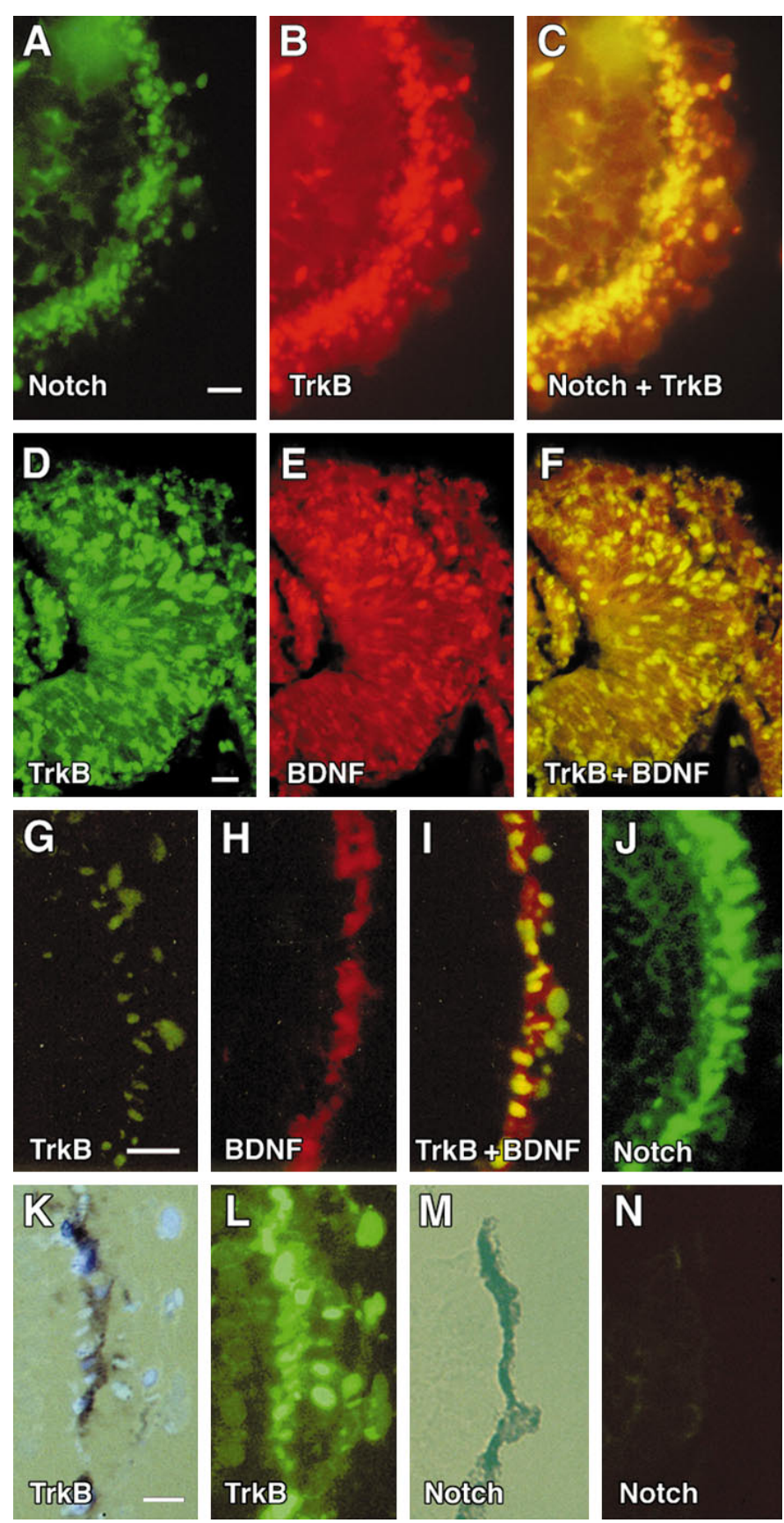

Figure 1. Co-Localization of Notch, TrkB, and BDNF in the developing optic cup. Top panels, FISH of stage 26 Xenopus optic cups (sagittal sections, en face). In $A-C$, a single section was probed with cRNA antisense probes incorporating fluorescein-12-UTP (Boeringer Mannheim) for Xenopus Notch $(A)$ or TMR-5-UTP (Molecular Probes) fluorescein isothiocianate for the kinase-containing domain of Xenopus trkB $(B)$ and Notch plus trkB $(C) . D-F$, FISH of stage 28 retinas (coronal sections) probed with FITC antisense riboprobes for trkB $(D)$, RITC probes for BDNF $(E)$, and FITC-trkB plus RITC-BDNF $(F)$. $G-J$, en face views of stage 30 Xenopus retinas probed with FITC-trkB $(G)$, RITC-BDNF $(H)$, FITC-trkB plus RITC-BDNF $(I)$, and FITC Notch $(J) . K$, Bright-field exposure of a stage 32 Xenopus retina probed with FITC-trkB $(L)$. M, Bright-field exposure of a stage 32 Xenopus retina probed with FITC-Notch $(N)$. Scale bar, $0.1 \mathrm{~mm}$.

\section{BDNF-blocking antibody inhibits RPE differentiation in vitro}

To test an autocrine role for BDNF in the differentiation of the RPE, serum-free explants of stage 26 optic vesicles were cultured
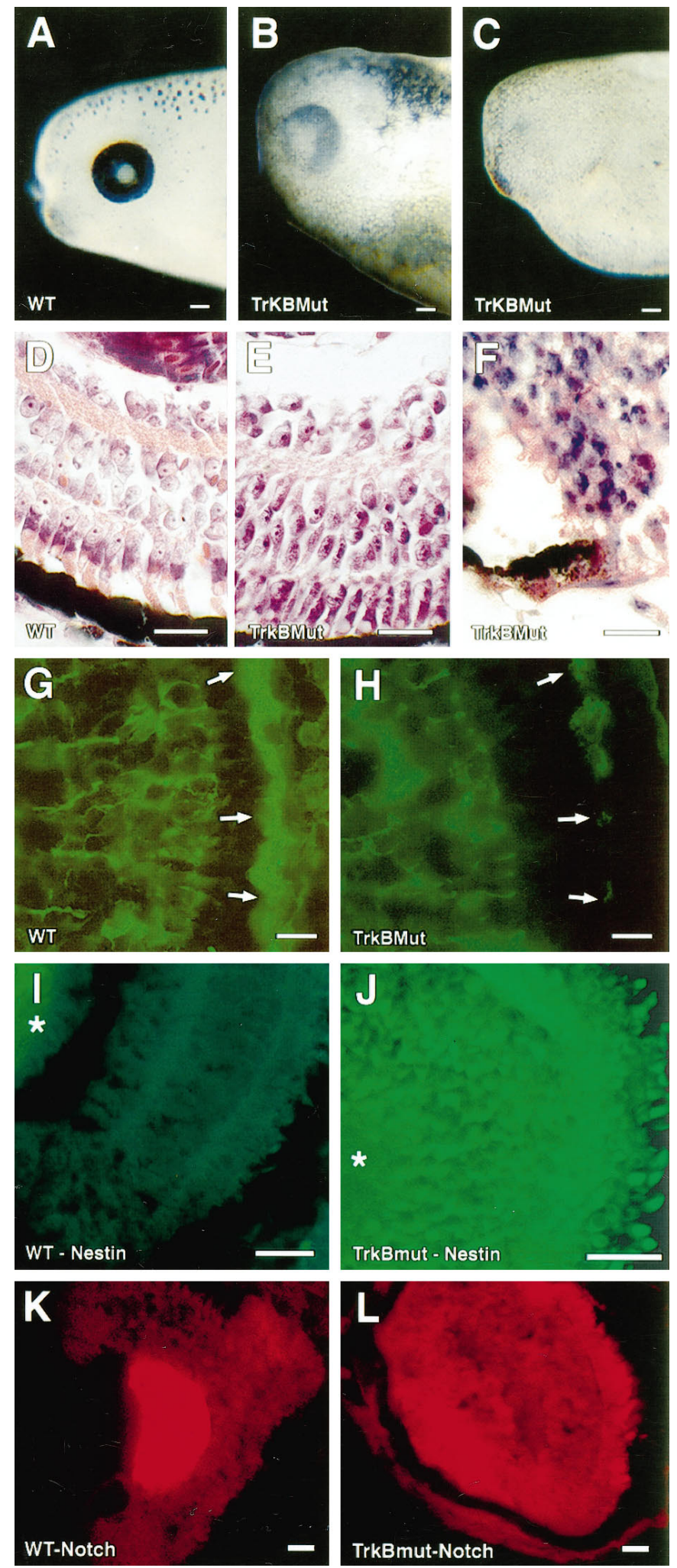

Figure 5. Retinal pigment abnormalities in dominant negative TrkB mutants. Representative photographs of the eyes of water-injected controls $(A)$ and the trkB dominant negative mutants $(B, C) . D-F$, Representative sections from the central retinas of cresyl violet-eosin-stained tissues. Embryos were generated simultaneously and killed at stage 45. A water-injected embryo is shown in $D$; mildly and severely affected embryos are seen in $E$ and $F$, respectively. Scale bar, $50 \mu \mathrm{m}$. $G, H$, Immunofluorescent sections from a stage 45 water-injected control embryo $(G)$ or mildly affected mutant $(H)$ probed with a (Figure legend continues) 
Day 1
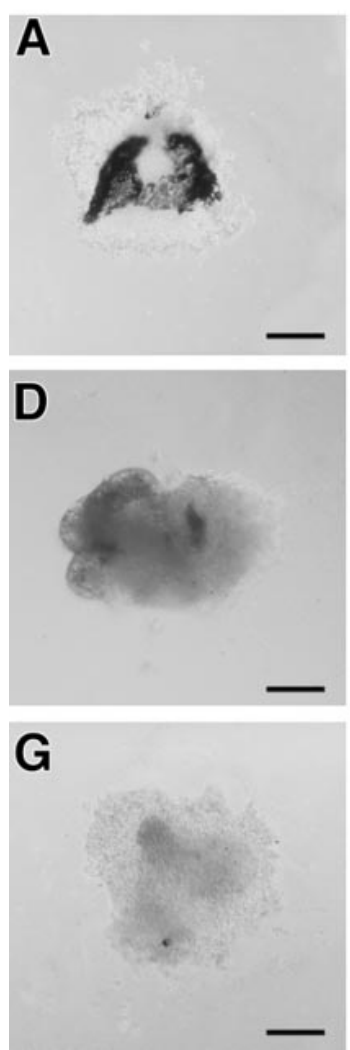

Day 3
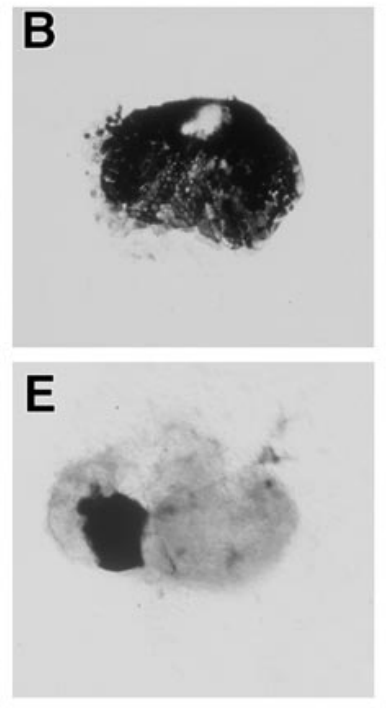

H

Figure 2. BDNF-blocking antibody prevents RPE differentiation in vitro. $A-C$, Representative control stage 26 explant at days 1,3 , and 5 after plating. $D-F$, Representative explant cultured in the presence of $15 \mu \mathrm{g} / \mathrm{ml} \mathrm{BDNF}$ antibody at days 1,3 , and 5 . $G-I$, Represented explant cultured in the presence of $50 \mu \mathrm{g} / \mathrm{ml} \mathrm{BDNF}$ antibody.
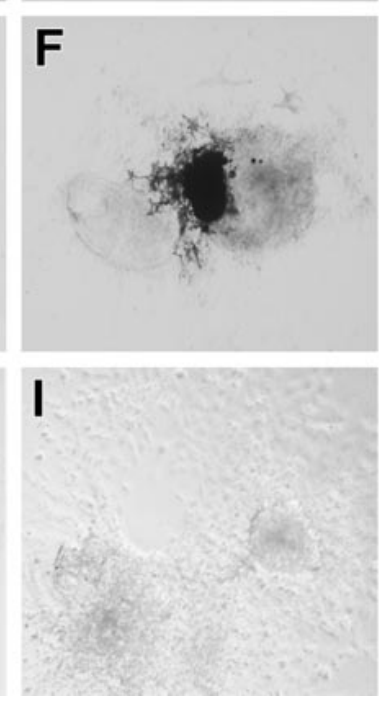

BDNF Ab $15 \mu \mathrm{g} / \mathrm{ml}$

Control

\section{BDNF Ab $50 \mu \mathrm{g} / \mathrm{ml}$}

in the absence or presence of a neutralizing antibody to BDNF (see Materials and Methods). Cultures were photographed on days 1, 3, and 5 after harvest. Representative photographs are shown in Figure 2. Control explants developed small clusters of pigmented cells by day 1 (Fig. $2 A$ ). By day 3 , these cells had coalesced into a sheet of cuboidal pigmented epithelium (Fig. $2 B$ ), which diminished somewhat by day 5 (Fig. 2C) (consistent with some cell death of pigmented cells). Cultures incubated in the presence of $15 \mu \mathrm{g} / \mathrm{ml}$ BDNF antibody $\left(\mathrm{ND}_{50}\right.$; see Materials and Methods) showed fewer clumps of pigmented cells (Fig. $2 D-F$ ) compared with controls (Fig. $2 A-C$ ). The death of pigmented cells was also noted between days 3 and 5 (Fig. 2E,F). At $50 \mu \mathrm{g} / \mathrm{ml}$ BDNF antibody $\left(\mathrm{ND}_{100}\right)$, a near-complete block of RPE differentiation was seen (Fig. $2 G-I$ ). Interestingly, nonpigmented cells continued to grow exuberantly (Fig. 2I).

\section{BDNF promotes survival of RPE in vitro}

To test for a survival-promoting effect of BDNF on the RPE, stage 45 optic cups were dissociated and then plated in the presence or absence of BDNF. Cultures were allowed to attach in media containing $10 \%$ FBS overnight, and then they were washed and maintained in serum-free media (see Materials and Methods) $\pm 100 \mathrm{ng} / \mathrm{ml} \mathrm{BDNF}$ (3.7 nM).

polyclonal antibody to CRALBP (Bunt-Milam and Saari, 1983). Arrows indicate the RPE layer. $I, J$, Immunofluorescent sections from stage 45 water-injected controls $(I)$ or a severely affected mutant $(J)$. Sections were probed with a polyclonal antibody raised against the intermediate filament nestin (Tohyama et al., 1992). $K, L$, Sections from a stage 45 water-injected control $(K)$ or severely affected trkB mutant $(L)$ probed with RITC antisense riboprobe for Xenopus Notch. Scale bar, $0.1 \mathrm{~mm}$.
Attachment rates (cell counts on day 2) were not significantly different between groups (control, $92 \% \pm 4$; BDNF, 93\% \pm 4 ; $p=0.38$ ). Survival data were displayed graphically in Figure 3. Percent survival was determined by comparing daily cell counts to the number of cells attached on day 2. Each data point represents the average of eight wells. A significantly higher rate of survival was noted in BDNF-treated cultures compared with controls $(p<0.001)$.

\section{Dominant negative TrkB mutant inhibits retinal differentiation in vivo: wild-type receptor rescues phenotype}

To study the developmental contribution of the trkB receptor to RPE differentiation, a dominant negative mutant of the trkB receptor was expressed in developing Xenopus. In previous work, we had found that substitution of a single-base pair (Lys $\rightarrow$ Met) at the ATP binding site of the trkB receptor could generate a noncatalytic receptor, which could dominantly inhibit BDNF signaling in vivo (Eide et al., 1996). This receptor was tagged at its $\mathrm{C}$ terminus with an epitope from the c-myc proto-oncogene (Evan et al., 1985) to facilitate its detection by Western blotting and immunohistochemistry. Wild-type trkB receptors used in rescue experiments were tagged with an epitope from influenza virus hemagglutinin (Niman et al., 1983). cRNAs encoding mutant and wild-type trkB receptors were generated by in vitro transcription and then microinjected into one-half of a two-cell Xenopus embryo as described previously by MacNicol et al. (1993). Figure 4 shows expression of the mutant receptor in embryo whole mounts (Fig. 4A), in paraffin section tissues (Fig. 4B), and in embryo lysates (Fig. 4C; Western blot).

Table 1 summarizes the results of the dominant negative trials. Embryos were allowed to develop until stage 45 and then scored 


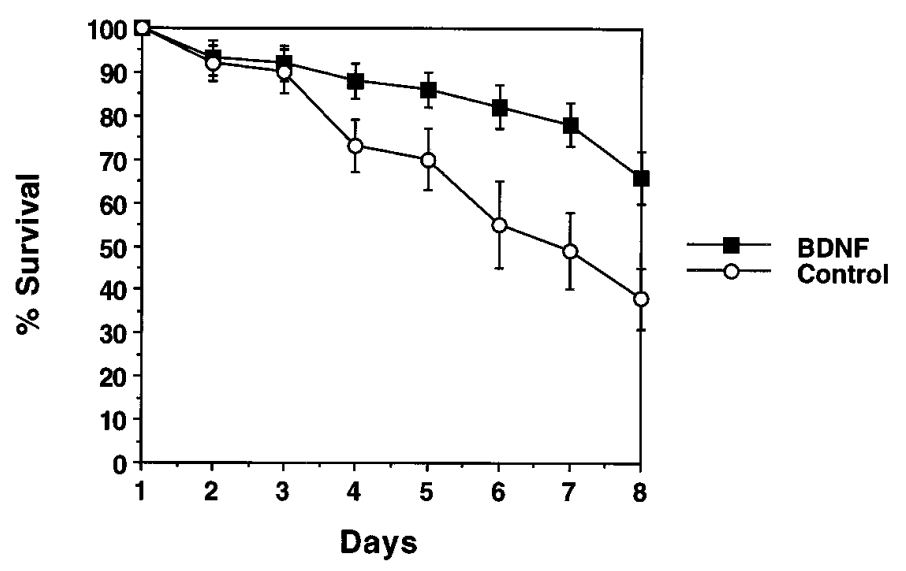

Figure 3. BDNF promotes RPE survival. The survival rates of dissociated RPE in the presence (black squares) or absence (white circles) of 100 $\mathrm{ng} / \mathrm{ml} \mathrm{BDNF}$ are shown. Points represent the average of eight wells. Error bars indicate SD.

for the presence of gross eye abnormalities. Three percent of uninjected embryos and $8 \%$ of water-injected embryos demonstrated some evidence of eye defects, compared with $40 \%$ of embryos injected with the trkB dominant negative mutant. There was no statistical difference between uninjected and waterinjected controls $(p=0.21)$. On the other hand, eye abnormalities among the trkB mutants were significantly different from controls $(p<0.0001)$. Co-injection of wild-type trkB receptors at a 1:1 ratio (wild-type trkB/mutant trkB) rescued the eye phenotype (14\%), supporting a specific effect of this mutant on trkBmediated pathways. Interestingly, this rescue brought the incidence of eye abnormalities to the point that it did not significantly differ from that of water-injected controls $(p=0.168)$. An increased death rate $(29 \%)$ was also noted among mutants compared with controls $(5 \%)(p<0.0001)$. Interestingly, co-injection of wild-type receptors also appeared to reverse this trend $(13 \%)$ $(p<0.002)$.

To determine whether any delay or deficiency of eye pigmentation was seen as the result of the trkB mutant, stage 32 embryos were scored for the presence of eye pigment. Ninety percent (26 of 29) of uninjected controls and $82 \%$ (18 of 22) of water-injected controls showed at least some evidence of eye pigmentation by this stage, compared with $21 \%$ (4 of 19) of trkB mutants $(p<$ $0.0001)$. The presence of eye pigmentation in $38 \%$ ( 8 of 21 ) of embryos co-injected with a 1:1 ratio of wild-type/mutant receptors suggested that this defect was also at least partially reversible.

\begin{tabular}{|c|c|c|}
\hline cRNA injected & $\begin{array}{l}\text { Eye abnormalities } \\
{[\%(n)]}\end{array}$ & $\begin{array}{l}\text { Deaths } \\
(\%)\end{array}$ \\
\hline Uninjected controls $(11 / 243)$ & $3(3 / 99)$ & 5 \\
\hline H2O-injected controls $(11 / 216)$ & $8(8 / 100)$ & 5 \\
\hline TrkBMut (2 ng/embryo) (108/378) & $40(27 / 67)$ & 29 \\
\hline TrkBMut:WT (2:2 ng/embryo) (51/396) & $14(21 / 154)$ & 13 \\
\hline
\end{tabular}

Figure 5, $A-C$, shows representative eyes of water-injected controls (Fig. 5A) and mildly affected (Fig. $5 B$ ) or severely abnormal (Fig. 5C) mutants. Some abnormality of RPE morphology (e.g., decreased pigmentation, decreased RPE thickness, and discontinuity) was noted in every abnormal trkB mutant examined at the light microscopic level (Fig. 5E,F). The most severely affected embryos showed complete absence of RPE (not shown).

Abnormalities of the neural retina were also quite prominent in the trkB dominant negative mutants. In mildly affected mutants (Fig. $5 E$ ), a laminar pattern of the neural retina was preserved; however, photoreceptors showed shortened outer segments and poorly formed synaptic pedicles, and cells of the inner nuclear layer retained an elongated columnar appearance, in addition to showing thinning of both plexiform layers. Immunofluorescent staining for CRALBP, a marker of differentiated RPE and muller glia (Bunt-Milam and Saari, 1983), showed weak staining of the RPE layer in mildly affected trkB mutants (Fig. 5H, arrows), consistent with the impaired differentiation of the RPE (Fig. 5G, arrows). Staining in muller glia was not significantly different from water-injected controls (Fig. 5G,H).

In severely affected embryos, most or all of the differentiated components of the retina appeared to be replaced by cells staining deeply with cresyl violet (Fig. $5 F$ ). These cells were identified as retinal neuroepithelia by the presence of nestin positivity (Fig. $5 J$ ) (Tohyama et al., 1992) and Notch mRNA (Fig. 5L). Some severely affected mutants showed rudimentary ganglion cell layers and photoreceptor rosettes in addition to dense collections of neuroblasts (data not shown). The identity of photoreceptors within rosette-like structures was confirmed by XAP1 staining (data not shown) (Harris and Messersmith, 1992).

\section{DISCUSSION}

Germinal retinal neuroepithelium consists of a large pool of cells competent for differentiation into diverse cell types (for review, see Austin et al., 1995; Cepko et al., 1996). As development
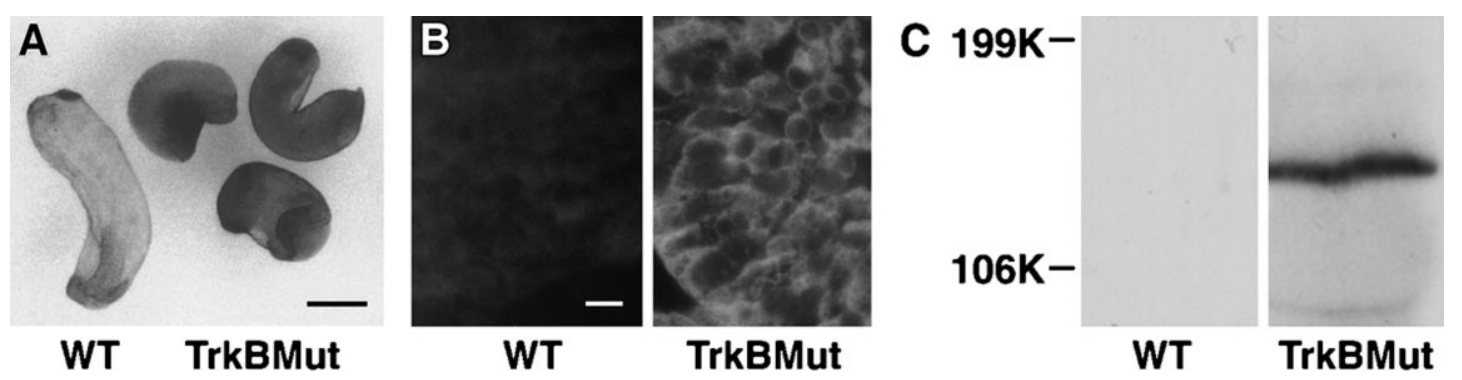

Figure 4. Expression of the Myc-tagged TrkB mutant. $A$, Whole-mount immunohistochemistry of stage 32 embryos using an anti-myc antibody (9E10). At left is an embryo injected with sterile water, at right, three mutants expressing the myc-tagged trkB mutant. Scale bar, $0.1 \mathrm{~mm}$. $B$, Immunofluorescent staining (using the 9E10 antibody) of the eyes of stage 26 embryos injected either with water (WT) or cRNA encoding the trkB mutant (TrkBMut). Scale bar, $10 \mu \mathrm{m}$. $C$, Western blot of stage 26 embryo lysates injected with either sterile water (WT) or cRNA encoding the myc-tagged trkB mutant (TrkBMut). A band at $145 \mathrm{kDa}$ corresponds to the mutant trkB receptor. 
proceeds, intrinsic and extrinsic factors begin segregating subsets of cells that will differentiate along divergent pathways. Here we have found that BDNF and its receptor trkB play a critical part in that segregation by directing uncommitted neuroblasts to differentiate into the retinal pigment epithelium.

In stage 26 of Xenopus, BDNF and trkB can be found broadly expressed in the germinal retinal neuroepithelium (Fig. $1 A-C$ ). By stage $28, \mathrm{BDNF}$ and trkB transcripts have clustered within subsets of cells appearing to represent different differentiating cell populations, including the presumptive RPE layer (Fig. $1 D-$ I). By stage 32, Notch transcripts were seen to downregulate in this layer (Fig. $1 M, N$ ), perhaps heralding the onset of RPE differentiation. Other groups have shown that Notch regulates alternative fates within equivalence groups by inhibiting subsets of cells that have an equivalent neural fate potential (for review, see Heitzler and Simpson, 1991). Within the Xenopus retina, Coffman et al. (1990) and Dorsky et al. (1995) have suggested that Notch plays a similar role, inhibiting the differentiation of certain subsets of neuronal precursors until later inductive signals restrict their cellular identities.

\section{Roles for BDNF and TrkB in RPE differentiation and survival}

In this study, an autocrine role for BDNF in RPE differentiation was confirmed by incubating serum-free cultures of stage 26 optic vesicles with a blocking antibody to BDNF. RPE differentiation was blocked in a dose-dependent manner by this antibody, whereas the growth of at least some neuronal elements appeared to continue exuberantly (Fig. 2).

Survival analysis (Fig. 3) showed that BDNF also had some survival-promoting effects; however, because a significant decrease in cell numbers was seen by day 7 (control cultures, 38\%; BDNF-treated cultures, 66\%), additional survival-promoting factors for the RPE are likely to be discovered in the future.

In the dominant negative phase of our experiments, expression of noncatalytic trkB receptors caused severe abnormalities of RPE development, which included a loss of RPE pigmentation, discontinuity of the RPE layer, and decreased expression of the differentiated marker CRALBP (Fig. 5F,H). The most severely affected embryos showed near-complete arrest of retinal development with persistence of nestin- and Notch-positive neuroblasts (Fig. 5J,L). The trkB embryos shared a number of abnormalities in common with RPE-ablated transgenic mice (diphtheria toxin expressed under an RPE-selective promoter) (Raymond and Jackson, 1995), including the loss of pigmentation and discontinuity in RPE layers, shortening of photoreceptor outer segments, and disrupted lamination of the retina. The RPE-ablated animals did not show any loss of differentiated cell types or accumulation of neuroblasts. Interestingly, Campochiaro and colleagues have recently identified a splice varient of the full-length trkB receptor that preferentially binds BDNF in adult human and bovine RPE (P. Campochiaro, unpublished observations). The presence of survival- and/or differentiation-promoting effects of BDNF in mature RPE could have future implications for the treatment of degenerative retinal diseases such as retinitis pigmentosa.

\section{BDNF, TrkB, and pigmented cells}

The presence of pigment abnormalities in the skin of the trkB mutants also raised the question of whether trkB receptors could be regulating broader effects on the melanogenic cascade instead of or in addition to multiple local effects on discrete pigmented cell groups. A complete answer to this question is beyond the scope of this paper; however, work from other groups at least suggests that BDNF and trkB mediate local trophic effects for diverse pigmented cell populations. In addition to mediating trophic effects in the RPE (present study), BDNF promotes the survival and/or differentiation of pigment-containing cells of the substantia nigra (Hyman et al., 1994), neural crest (LangtimmSedlak et al., 1996), and locus coeruleus (Sklair-Tavron and Nestler, 1995). Interestingly, the ability of BDNF to increase dopamine uptake and content in nigral neurons (Hyman et al., 1994) likely has implications for melanogenesis in these cells.

Although deficits of pigmentation appeared to occur early in the pathogenic process of the dominant negative mutants, we believe that the ocular phenotype in these embryos (e.g., loss of differentiated cell types and persistence of neuroblasts) is unlikely to result from a deficiency of pigmentation alone. Developmental defects associated with amelanotic retinas are well known to occur, but they have generally been limited to an absence of the fovea centralis (Klintworth, 1994), abnormalities of photoreceptor synapses and segments (Perez and Perentes, 1994; Szczesny et al., 1996), and projection of the temporal retina onto contralateral brain (Klintworth, 1994). Furthermore, the analysis of mildly affected trkB mutants in this study also showed an early loss of CRALBP expression (Fig. 5H), consistent with either an early impairment RPE differentiation or an early loss of differentiated RPE.

\section{Comparison of Xenopus trkB dominant negative and transgenic mouse knock-outs}

The severity of the eye abnormalities observed in the dominant negative mutants contrasted sharply with the normal ocular phenotypes reported in trkB, BDNF, and BDNF plus neurotrophin4/5 knock-out mice (Klein et al., 1993; Jones et al., 1994; Conover et al., 1995). Reasons for this discrepancy are not entirely clear; however, fundamental differences between the paradigms could account for some significant differences in phenotypic outcomes. Murine knock-out experiments, for instance, cause permanent and complete disruptions of genes before the onset of conception, whereas dominant negative experiments in Xenopus cause transient incomplete inhibitions of gene function; the inhibition of gene function in Xenopus varies both in the time of onset as well as in its duration (Vize et al., 1991). A difference in any of these variables could result in a differential activation of compensatory growth factor pathways or other developmental pathways, causing significant differences in phenotypic outcomes. Perhaps the use of conditional or retinal layer-specific promoters in future experiments will help elucidate cell-specific contributions of trkB receptor pathways within the developing retina.

\section{REFERENCES}

Angerer LM, Stoler MH, Angerer RC (1987) In situ hybridization with RNA probes: an annotated recipe. In: In situ hybridization: applications to neurobiology (Valentino KL, Eberwine J, Barchas J, eds), pp 43-70. New York: Oxford UP.

Artavanis-Tsakonis S, Delidakis C, Fehon RG (1991) The notch locus and the cell biology of neuroblast segregation. Annu Rev Cell Biol 7:427-452.

Austin CP, Feldman DE, Ida JA, Cepko CL (1995) Vertebrate retinal ganglion cells are selected from competent progenitors by the action of Notch. Development 121:3637-3650.

Bok D (1993) The retinal pigment epithelium: a versatile partner in vision. J Cell Sci Suppl 17:189-195.

Bovolenta P, Frade J-M, Marti E, Rodriguez-Pena M-A, Barde Y-A, Rodriguez-Tebar A (1996) Neurotrophin-3 antibodies disrupt the normal development of the chick retina. J Neurosci 16:4402-4410. 
Brill G, Kahane N, Carmeli C, vonSchack D, Barde YA, Kalcheim C (1995) Epithelial-mesenchymal conversion of dermatome progenitors requires neural tube-derived signals: characterization of the role of neurotrophin-3. Development 121:2583-2594.

Bunt-Milam AH, Saari JC (1983) Immunocytochemical localization of two retinoid-binding proteins in vertebrate retina. J Cell Biol 97:703-712.

Cepko CL, Austin CP, Yang XJ, Alexiades M (1996) Cell fate determination in the vertebrate retina. Proc Natl Acad Sci USA 93:589-595.

Coffman C, Harris W, Kintner C (1990) Xotch, the Xenopus homologue of Drosophila Notch. Science 249:1438-1441.

Cohen-Cory S, Fraser SE (1994) BDNF in the development of the visual system of Xenopus. Neuron 12:747-761.

Cohen-Cory S, Escandon E, Fraser SE (1996) The cellular patterns of $\mathrm{BDNF}$ and trkB expression suggest multiple roles for BDNF during Xenopus visual system development. Dev Biol 179:102-115.

Collett D (1994) In: Modelling survival data in medical research, pp 17-19, 40-43. London: Chapman and Hall.

Conover JC, Erickson JT, Katz DM, Bianchi LM, Poueymirou WT, McClain J, Pan L, Helgren M, Ip NY, Boland P, Friedman B, Wiegand S, Vejsada R, Kato AC, DeChiara TM, Yancopoulos GD (1995) Neuronal deficits, not involving motor neurons, in mice lacking BDNF and/or NT4. Nature 375:235-238.

Defoe DM, Easterling KC (1994) Reattachment of retinas to cultured pigment epithelial monolayers from Xenopus laevis. Invest Ophthalmol Vis Sci 35:2466-2476.

Dorsky RI, Rapaport DH, Harris WA (1995) Xotch inhibits cell differentiation in the Xenopus retina. Neuron 14:487-496.

Eide FF, Lowenstein DH, Reichardt LF (1993) Neurotrophins and their receptors-current concepts and implications for neurologic disease. Exp Neurol 121:200-214.

Eide FF, Vining ER, Eide BL, Zang K, Wang XY, Reichardt LF (1996) Naturally occurring truncated trkB receptors have dominant inhibitory effects on BDNF signaling. J Neurosci 16:3123-3129.

Evan GI, Lewis GK, Ramsay G, Bishop JM (1985) Isolation of monoclonal antibodies specific for human $c$-myc proto-oncogene product. Mol Cell Biol 5:3610-3616.

Frade JM, Marti E, Bovolenta P, Rodriguez-Pena MA, Perez-Garcia D, Rohrer H, Edgar D, Rodriguez-Tebar A (1996) Insulin-like growth factor-I stimulates neurogenesis in chick retina by regulating expression of the $\alpha 6$ integrin subunit. Development 122:2497-2506.

Hallbook F, Ibanez CF, Ebendal T, Persson H (1993) Cellular localization of brain- derived neurotrophic factor and neurotrophin-3 mRNA expression in the early chicken embryo. Eur J Neurosci 5:1-14.

Harris WA, Messersmith SL (1992) Two cellular inductions involved in photoreceptor determination in the Xenopus retina. Neuron 9:357-372.

Heitzler P, Simpson P (1991) The choice of cell fate in the epidermis of Drosophila. Cell 64:1083-1092.

Hyman C, Juhasz M, Jackson C, Wright P, Ip NY, Lindsay RM (1994) Overlapping and distinct actions of the neurotrophins BDNF, NT-3, and NT-4/5 on cultured dopaminergic and GABAergic neurons of the ventral mesencephalon. J Neurosci 14:335-347.

Jones KR, Farinas I, Backus C, Reichardt LF (1994) Targeted disruption of the BDNF gene perturbs brain and sensory neuron development but not motor neuron development. Cell 76:989-999.

Kelley MW, Turner JK, Reh TA (1994) Retinoic acid promotes differentiation of photoreceptors in vitro. Development 120:2091-2102.

Klein R, Smeyne RJ, Wurst W, Long LK, Auerback BA, Joyner AL, Barbacid M (1993) Targeted disruption of the trkB neurotrophin receptor gene results in nervous system lesions and neonatal death. Cell 75:113-122.

Klintworth, GK (1994) Disorders of amino acid metabolism and melanin pigmentation. In: Pathobiology of ocular disease (Garner A, Klintworth GK, eds), pp 939-971. New York: Dekker.

Klymkowsky MW, Hanken J (1991) Whole-mount staining of Xenopus and other vertebrates. In: Xenopus laevis: practical uses in cell and molecular biology (Kay BK, Peng HB, eds), pp 419-441. San Diego: Academic.

Koide T, Takahashi JB, Hoshimaru M, Kojima M, Otsuka T, Asahi M, Kikuchi H (1995) Localization of trkB and low-affinity nerve growth factor receptor mRNA in the developing rat retina. Neurosci Lett 185:183-186.

Krieg PA, Melton DA (1984) Functional messenger RNAs are produced by SP6 in vitro transcription of cloned cDNAs. Nucleic Acids Res 12:7057-7070.
Laemmli UK (1970) Cleavage of structural proteins during the assembly of the head of bacteriophage T4. Nature 227:680-685.

Langtimm-Sedlak CJ, Schroeder B, Saskowski JL, Carnahan JF, SieberBlum M (1996) Multiple actions of stem cell factor in neural crest cell differentiation in vitro. Dev Biol 174:345-359.

LaVail MM, Unoki K, Yasumura D, Matthes MT, Yancopoulos GD, Steinberg RH (1992) Multiple growth factors, cytokines, and neurotrophins rescue photoreceptors from the damaging effects of constant light. Proc Natl Acad Sci USA 89:11249-11253.

MacNicol AM, Muslin AJ, Williams LT (1993) Raf-1 kinase is essential for early Xenopus development and mediates the induction of mesoderm by FGF. Cell 73:571-583.

Mitsiadis TA, Luukko K (1995) Neurotrophins in odontogenesis. Int J Dev Biol 39:195-202.

Nieuwkoop PD, Faber J (1956) Normal table of Xenopus laevis (Daudin). Amsterdam: North Holland.

Niman HL, Houghten RA, Walker LE, Reisfeld RA, Wilson IA, Hogle JM, Lerner RA (1983) Generation of protein-reactive antibodies by short peptides is an event of high frequency: implication for the structural basis of immune recognition. Proc Natl Acad Sci USA 80:4949-4953.

Okazawa H, Kamei M, Imafuku I, Kanazawa I (1994) Gene regulation of trkB and trkC in the chick retina by light/darkness exposure. Oncogene 9:1813-1818.

O'Keefe HP, Melton,DA, Ferreiro B, Kintner C (1991) In situ hybridization. In: Xenopus laevis: practical uses in cell and molecular biology (Kay BK, Peng HB, eds), pp 443-463. San Diego: Academic.

Park CM, Hollenberg, MJ (1993) Growth factor-induced retinal regeneration in vivo. Int Rev Cytol 146:49-74.

Perez J, Perentes E (1994) Light-induced retinopathy in the albino rat in long-term studies. An immunohistochemical and quantitative approach, Exp Toxicol Pathol 46:229-235.

Perez M-TR, Caminos E (1995) Expression of brain-derived neurotrophic factor and of its functional receptor in neonatal and adult retina. Neurosci Lett 183:96-99.

Pittack C, Reh TA (1994) Acidic and basic fibroblast growth factor play a significant role in the development of the neural retina in the chick embryo. Soc Neurosci Abstr 20:280.13.

Pittack C, Jones M, Reh TA (1991) Basic fibroblast growth factor induces retinal pigment epithelium to generate neural retina in vitro Development 113:577-588.

Raymond SM, Jackson IJ (1995) The retinal pigment epithelium is required for development and maintenance of the mouse neural retina. Curr Biol 5:1286-1295.

Rosner B (1995) In: Fundamentals of biostatistics, pp 346-349. Belmont, CA: Duxbury.

Sklair-Tavron L, Nestler EJ (1995) Opposing effects of morphine and the neurotrophins, NT-3, NT-4, and BDNF, on locus coeruleus neurons in vitro. Brain Res 702:117-125.

Szczesny PJ, Walther P, Muller M (1996) Light damage in rod outer segments: the effects of fixation on ultrastructural alterations. Curr Eye Res 15:807-814.

Tohyama T, Lee VM, Rorke LB, Marvin M, McKay RD, Trojanowski JQ (1992) Nestin expression in embryonic human neuroepithelium and in human neuroepithelial tumor cells. Lab Invest 66:303-313.

Tomita K, Ishibashi M, Nakahara I, Ang SL, Nakanishi S, Guillemot F, Kageyama R (1996) Mammalian hairy and Enhancer of Split homolog 1 regulates differentiation of retinal neurons and is essential for eye morphogenesis. Neuron 16:723-734.

Ugolini G, Cremisi F, Maffei L (1995) TrkA, TrkB and p75 mRNA expression is developmentally regulated in the rat retina. Brain Res 704:121-124.

Unoki K, LaVail MM (1994) Protection of the rat retina from ischemic injury by brain-derived neurotrophic factor, ciliary neurotrophic factor, and basic fibroblast growth factor. Invest Ophthalmol Vis Sci 35:907-915.

Vize PD, Melton DA, Hemmati-Brivanlou A, Harland RM (1991) Assays for gene function in developing Xenopus embryos. In: Xenopus laevis: practical uses in cell and molecular biology (Kay BK, Peng HB, eds), pp 367-387. San Diego: Academic.

Wheeler EF, Bothwell M (1992) Spatiotemporal patterns of expression of NGF and the low-affinity NGF receptor in rat embryos suggest functional roles in tissue morphogenesis and myogenesis. J Neurosci 12:930-945. 